\title{
Preclinical science regarding cannabinoids as analgesics: An overview
}

\author{
ME Lynch MD FRCPC
}

\begin{abstract}
ME Lynch. Preclinical science regarding cannabinoids as analgesics: An overview. Pain Res Manage 2005;10(Suppl A): 7A-14A.

Modern pharmacology of cannabinoids began in 1964 with the isolation and partial synthesis of delta-9-tetrahydrocannabinol, the main psychoactive agent in herbal cannabis. Since then, potent antinociceptive and antihyperalgesic effects of cannabinoid agonists in animal models of acute and chronic pain; the presence of cannabinoid receptors in pain-processing areas of the brain, spinal cord and periphery; and evidence supporting endogenous modulation of pain systems by cannabinoids has provided support that cannabinoids exhibit significant potential as analgesics. The present article presents an overview of the preclinical science.
\end{abstract}

Key Words: Cannabinoid opioid interactions; Cannabinoid receptors; Cannabinoids; Chronic pain; Endocannabinoids

$\mathrm{H}$ erbal cannabis has been used for centuries for medicinal and recreational purposes, but it has only been in the past 40 years that scientists have been able to elucidate the molecular basis of cannabinoid action.

Modern pharmacology of cannabinoids began in 1964 when the major psychoactive constituent of cannabis, delta-9tetrahydrocannabinol $(\Delta-9-\mathrm{THC})$, was isolated in pure form, its structure elucidated and later synthesized (1). Since then, the endogenous cannabinoid (endocannabinoid) system has been described, stimulating the development of a range of novel cannabinoid receptor agonists and antagonists (2). These developments have attracted renewed interest in the cannabinoids as potential therapeutic agents. In less than five years there have been over 1500 citations on MEDLINE regarding cannabinoids, and the rate of publications in the field is growing rapidly (Figure 1).

Areas of inquiry include the potential role of cannabinoids in pain, antiemesis, appetite modulation, antispasticity, neuroprotection, anti-inflammatory action, tumour suppression, antioxidant activity, immune modulation, glaucoma, sexual dysfunction and addiction control. The present paper will focus on the preclinical literature regarding cannabinoids and pain. There are already a number of excellent reviews on this topic (2-7), and the current article will present an overview of the field.

\section{ENDOCANNABINOID SYSTEM}

The first crucial step in elucidating the molecular basis of cannabinoid action was achieved in 1988. At that time, a radiolabelled potent synthetic cannabinoid was found to bind to brain membranes in a highly specific and selective manner,

\author{
Survol des données précliniques sur les \\ propriétés analgésiques des cannabinoïdes
}

C'est en 1964 qu'est née la pharmacologie moderne des cannabinoïdes, quand on a isolé et partiellement synthétisé le delta-9-tétrahydrocannabinol, principal agent psychoactif de la plante appelée cannabis. Depuis lors, les puissants effets antinociceptifs et antihyperalgésiques des agonistes des cannabinoïdes dans des modèles animaux de douleur aiguë et chronique, la découverte de récepteurs des cannabinoïdes dans les zones du cerveau, de la moelle épinière et du système nerveux périphérique responsables de la perception de la douleur et les preuves à l'appui d'une modulation endogène des stimuli douloureux par les cannabinoïdes confirment leur important potentiel analgésique. Le présent article propose une vue d'ensemble des données précliniques. exhibiting features that were characteristic of receptor binding (8). Within a short time, the cannabinoid receptor (now called $\mathrm{CB}_{1}$ ) was discovered and cloned from rat and human brain (9). Three years later, a second cannabinoid receptor $\left(\mathrm{CB}_{2}\right)$ was discovered and cloned (10). Since then, researchers around the world have mapped the location of $\mathrm{CB}_{1}$ and $\mathrm{CB}_{2}$ receptors, identified a probable third receptor, and described additional endocannabinoids as well as mechanisms and sites of action.

\section{Distribution of cannabinoid receptors}

$\mathrm{CB}_{1}$ receptors are found in particularly high concentrations within the central nervous system; indeed, $\mathrm{CB}_{1}$ receptors are 10 times more abundant than mu opioid receptors in the brain (11). $\mathrm{CB}_{1}$ receptors are also present in peripheral neurons and in non-neuronal tissues. The distribution of cannabinoid receptors has been examined by several methods (12-14). High levels of $\mathrm{CB}_{1}$ receptors have been found in the hippocampus, basal ganglia, hypothalamus, cerebellum, areas of the cerebral cortex and the nucleus accumbens, with implications for memory, coordination, feeding, higher cognitive function and reward. Most important for pain are moderately abundant concentrations located within the periaqueductal gray (PAG) of the midbrain, the rostral ventrolateral medulla (RVM), superficial layers of the spinal dorsal horn and dorsal root ganglion, from which they are transported to the peripheral and central terminals of the primary afferent neuron (Figure 2). These locations are important in descending pain modulation, spinal processing of pain and peripheral pain perception. Additional areas include the hypothalamus and the pituitary gland (temperature regulation, endocrine and reproductive function), the 


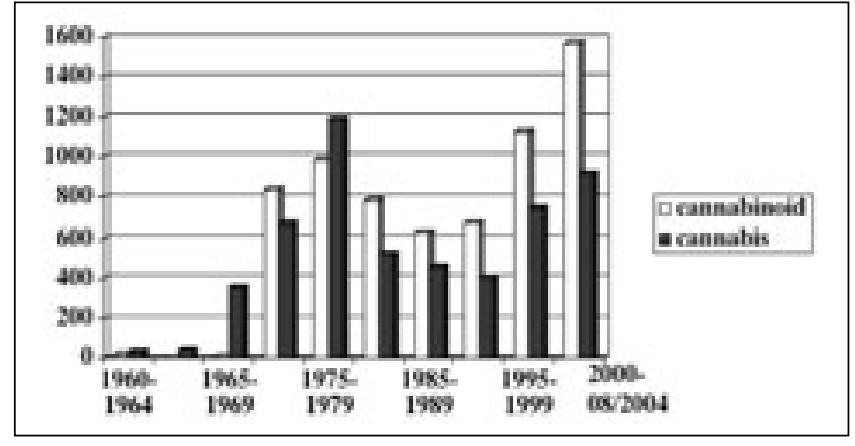

Figure 1) Number of PUBMED citations per five-year period regarding 'cannabinoid' and 'cannabis' research

amygdala (emotional response and fear), the brainstem (arousal) and the nucleus of the solitary tract (nausea and vomiting) (2,12,15-21) (Figure 2).

There are low levels of cannabinoid receptors in brainstem cardiopulmonary centres, which probably accounts for the high safety margin of the cannabinoids (5). The identification of receptors in the areas described above is consistent with the behavioural effects produced by cannabinoids.

The first $\mathrm{CB}_{2}$ receptors were cloned not from brain, but from a human immune cell line (12); thus, it was apparent from the beginning that the cannabinoid system extended beyond the nervous system. Since that time, studies have demonstrated the presence of $\mathrm{CB}_{2}$ receptors throughout the immune system $(22,23)$.

This work has established the current model for cannabinoid receptors, with $\mathrm{CB}_{1}$ primarily located in brain and associated structures such as the pituitary gland and peripheral nervous tissues, and $\mathrm{CB}_{2}$ primarily located in the reproductive and immune systems $(2,23)$. Recently, $\mathrm{CB}_{2}$ receptor-like immunoreactivity has been described in the rat brain in neuronal patterns supporting possible broader central nervous system roles for the $\mathrm{CB}_{2}$ receptor (24).

\section{Endocannabinoids}

Until the end of the 20th century, only two major endocannabinoids, anandamide ( $\mathrm{N}$-arachidonoyl-ethanolamine [AEA]) and 2-arachidonylglycerol (2-AG) had been discovered (25-27). Since then, additional endocannabinoids have been identified (28). These include noladin ether, virodhamine (O-arachidonoyl-ethanolamine) and $\mathrm{N}$-arachidonoyl dopamine (NADA) (29-31), as well as others that are in the process of being identified.

To qualify as an endocannabinoid, the agent must exhibit activity at cannabinoid receptors. The endocannabinoids vary in their activity at the receptor depending on the type of intracellular event measured (32). AEA, NADA and noladin are more selective for $\mathrm{CB}_{1}$, virodhamine appears to prefer $\mathrm{CB}_{2}$ and 2-AG is equipotent for both $\mathrm{CB}_{1}$ and $\mathrm{CB}_{2}$ (28). In addition to $\mathrm{CB}_{1}$ agonist activity, $\mathrm{AEA}$ binds to the vanilloid receptor (29). NADA also exhibits activity at vanilloid receptors (now called transient receptor potential vanilloid 1 receptors) and appears to be pronociceptive (28). Palmitoylethanolamide (PEA) is not strictly an endocannabinoid, but has cannabinomimetic properties, including analgesic effects, which in vivo are antagonized by the $\mathrm{CB}_{2}$ receptor antagonist SR144528 (7) (Table 1).

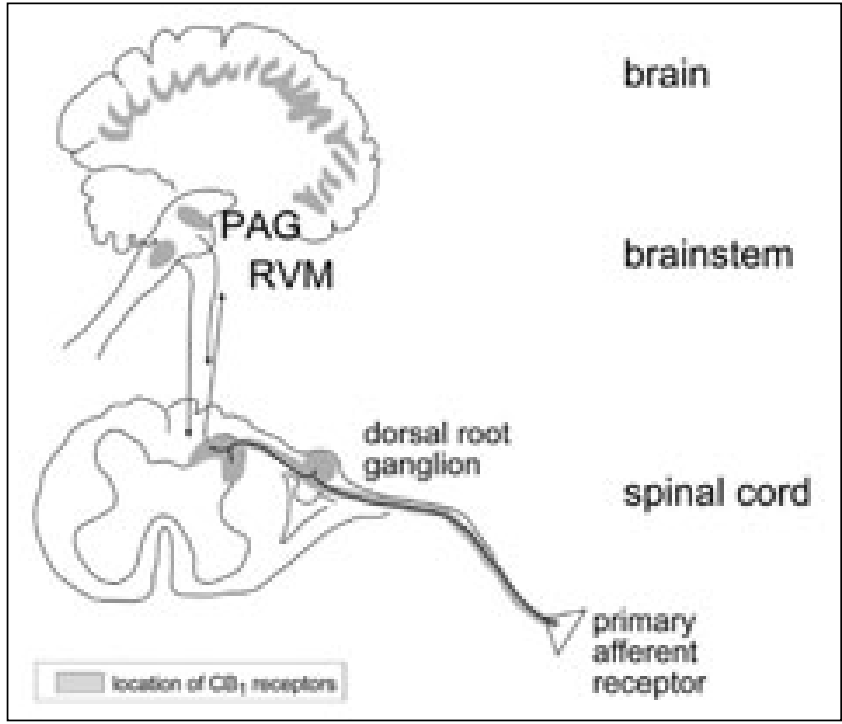

Figure 2) Location of cannabinoid receptors $\left(\mathrm{CB}_{1}\right)$ in the areas of the nervous system that are important for pain transmission and modulation. PAG Periaqueductal gray; RVM Rostral ventrolateral medulla

Biosynthesis and inactivation of endocannabinoids Endocannabinoids are biosynthesized via a phospholipiddependent pathway (Figure 3). The metabolic pathway for AEA and 2-AG have been identified; the detailed biosynthesis of the more recently discovered endocannabinoids is currently being worked out (28). The balance of evidence supports that AEA and 2-AG are synthesized and released on demand following physiological and pathological stimuli such as neuronal depolarization and the presence of bacterial lipopolysaccharides, possibly depending on calcium-dependent remodelling of phospholipid precursors. After biosynthesis, AEA and 2-AG are immediately released into the extracellular space. The release, disposition and potential recycling of endocannabinoids is not well understood. Research groups are pursuing various lines of inquiry, including identification of a putative transporter, uptake via caveolin-mediated endocytosis and passive diffusion. Inactivation of AEA and 2-AG occurs via fatty acid amide hydrolase (FAAH) and monoacylglycerol lipase, respectively $(4,6,28,33)$.

\section{CANNABINOID PHARMACOLOGY, MECHANISMS AND SITES OF ACTION}

There are several chemical classes of cannabinoid receptor agonists. These are the 'classical' cannabinoid $\Delta-9-$ THC, the 'nonclassical' cannabinoid CP55,940, the aminoalkylindole WIN55,212-2, the 'eicosanoid' cannabinoid AEA, and additional fatty acid ethanolamides and esters that act as endocannabinoids $(2,4)$. As with the endocannabinoids, there is variability regarding the activity of cannabinoid ligands at the receptor. For example, $\Delta-9-$ THC and CP55,940 exhibit equal affinity for $\mathrm{CB}_{1}$ and $\mathrm{CB}_{2}$, whereas WIN55,212-2 exhibits modest selectivity for $\mathrm{CB}_{2}(2)$. Table 1 presents further detail regarding endogenous, naturally occurring and synthetic cannabinoids and their activity at receptors known to date.

Signal transduction at the $\mathrm{CB}_{1}$ receptor

Both cannabinoid receptor types are embedded in the cell membrane and are coupled to $G$ proteins, negatively to adenylyl 
TABLE 1

\begin{tabular}{|c|c|c|c|}
\hline & Agent & Action & Comments \\
\hline \multirow[t]{2}{*}{ Naturally occurring cannabinoids } & $\Delta-9-\mathrm{THC}$ & $\mathrm{CB}_{1}$ and $\mathrm{CB}_{2}$ agonist & Main psychoactive constituent of cannabis \\
\hline & Cannabidiol & Unknown mode of action & Nonpsychoactive constituent of cannabis \\
\hline \multirow[t]{6}{*}{ Endogenous cannabinoids } & Anandamide & $\mathrm{CB}_{1}$ partial agonist & Also binds to TRPV1 \\
\hline & 2-Arachidonylglycerol & $\mathrm{CB}_{1}$ and $\mathrm{CB}_{2}$ agonist & \\
\hline & Noladin & $\mathrm{CB}_{1}$ & \\
\hline & $\mathrm{N}$-arachidonoyl dopamine & $\mathrm{CB}_{1}$ and TRPV1 agonist & Pronociceptive \\
\hline & Virodhamine & $\mathrm{CB}_{2}$ partial agonist & \\
\hline & & $\mathrm{CB}_{1}$ antagonist & \\
\hline
\end{tabular}

Palmitoylethanolamide

\begin{abstract}
Acts like a $\mathrm{CB}_{2}$ agonist with analgesic effects antagonized by $\mathrm{CB}_{2}$ antagonist but does not bind to $\mathrm{CB}_{2}$ receptors
\end{abstract}

Available by prescription in Canada

Available by prescription in Canada

$\begin{array}{lll}\text { Synthetic cannabinoids } & \begin{array}{l}\text { Nabilone } \\ \text { Synthetic } \Delta-9-\mathrm{THC} \text { (dronabinol; }\end{array} & \mathrm{CB}_{1} \text { and } \mathrm{CB}_{2} \text { agonist } \\ \text { Marinol [Solvay Pharma Inc, Canada]) } & \mathrm{CB}_{1} \text { and } \mathrm{CB}_{2} \text { agonist } \\ \text { CP55,940 } & \mathrm{CB}_{1} \text { and } \mathrm{CB}_{2} \text { agonist } \\ \text { WIN55,212-2 } & \mathrm{CB}_{1} \text { and } \mathrm{CB}_{2} \text { agonist } \\ \text { AM1241 } & \mathrm{CB}_{2} \text { agonist } \\ \text { HU-210 } & \mathrm{CB}_{1} \text { and } \mathrm{CB}_{2} \text { agonist } \\ \text { HU-211 } & \mathrm{Not}_{\text {active at cannabinoid receptors }} \quad \text { Neuroprotective } \\ \text { SR141716A } & \mathrm{CB}_{1} \text { antagonist } \\ \text { SR144528 } & \mathrm{CB}_{2} \text { antagonist } \\ \text { AM251 } & \mathrm{CB}_{1} \text { antagonist } \\ \text { AM630 } & \mathrm{CB}_{2} \text { antagonist }\end{array}$

${ }^{\star}$ This is not an exhaustive list. $\Delta-9-T H C$ Delta-9-tetrahydrocannabinol; $C B_{1}$ Cannabinoid receptors found primarily in the nervous system; $C B_{2}$ Cannabinoid receptors found primarily in peripheral tissues and immune system; TRPV1 Transient receptor potential vanilloid 1

cyclase and positively to mitogen-activated protein kinase $(2,6,7) \cdot \mathrm{CB}_{1}$ receptors are coupled to ion channels through $\mathrm{G}$ proteins, positively to A-type and inwardly rectifying potassium channels and negatively to $\mathrm{N}$-type and $\mathrm{P} / \mathrm{Q}$-type calcium channels and to D-type potassium channels (2). Activation of either receptor will result in inhibition of adenylyl cyclase activity resulting in a decrease in the production of cyclic AMP (cAMP) and cellular activities dependent on cAMP, with opening of inwardly rectifying potassium channels resulting in decreased cell firing and closing of calcium channels resulting in decreased release of neurotransmitters (Figure 4). The overall effect is that of cellular inhibition. This is very much like the mechanism of action of the opioids. The cannabinoids and opioids have similar actions but involve different systems. The $\mathrm{CB}_{1}$ receptor antagonist SR141716A prevents the analgesic effects of THC but not of morphine (34), whereas naloxone, an opioid antagonist, blocks the analgesic effect of morphine but not of THC and its analogues (35).

Thus, with regard to signal transduction at the $\mathrm{CB}_{1}$ receptor, cannabinoids exhibit actions very much like the morphine group of drugs, but are able to act independently. The cannabinoid system is larger and occupies more areas than the opioid system, with the implication that the cannabinoid system may have wider potential therapeutic applications.

Endocannabinoid signalling in the brain

In contrast to classical neurotransmitters, investigators have identified that endocannabinoids are able to function as retrograde synaptic messengers (36). In this case, the endocannabinoid is

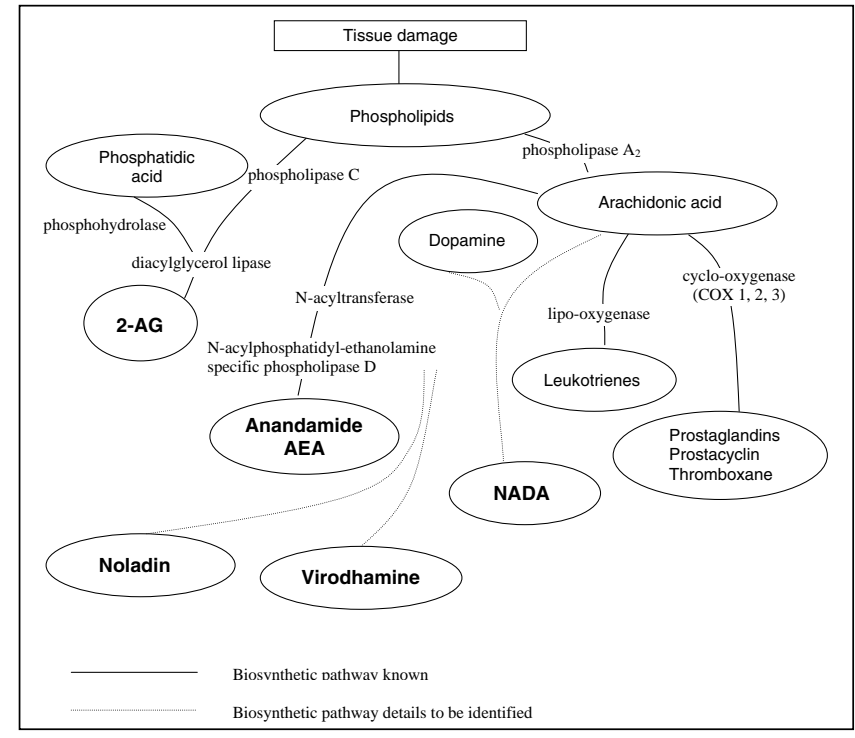

Figure 3) Biosynthesis of endocannabinoids in the context of the arachidonic acid pathway following tissue damage. 2-AG 2-arachidonylglycerol; AEA N-arachidonoyl-ethanolamine; NADA N-arachidonoyl dopamine

synthesized and released from the postsynaptic neurons to travel backwards across the synapse, activating $\mathrm{CB}_{1}$ on presynaptic axons and then suppressing neurotransmitter release. This capacity for 'working backwards' is directly relevant to pain modulation. 


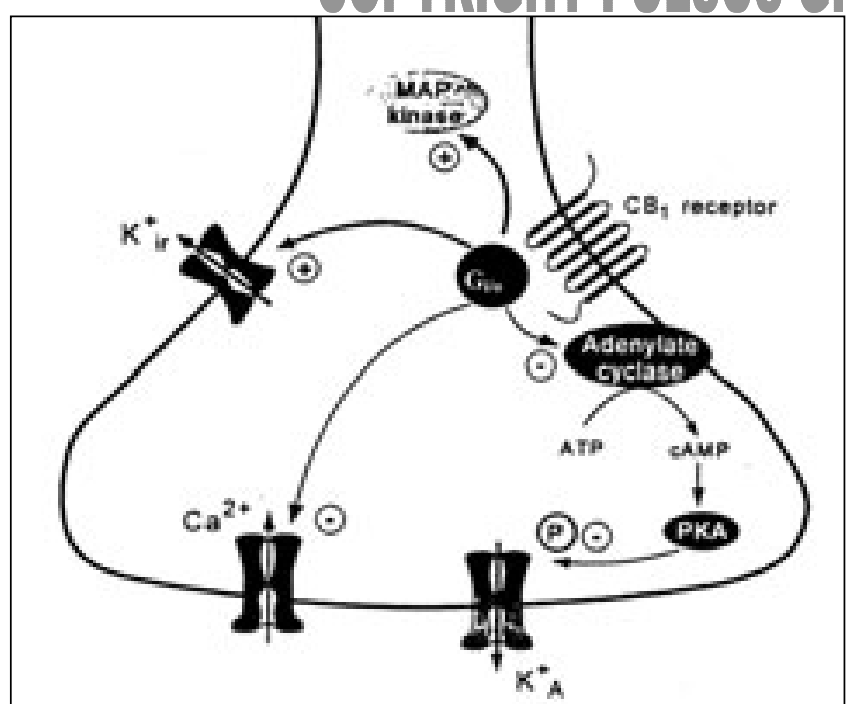

Figure 4) Signal transduction mechanisms at the cannabinoid receptor found primarily in the nervous system $\left(\mathrm{CB}_{1}\right)$. Activation of the receptor stimulates coupling to the $G$ protein with activation of mitogen-activated protein (MAP) kinase and inhibition of adenylyl cyclase with decreased production of cyclic (c)AMP. The G protein also directly couples the $\mathrm{CB}$ receptor negatively to $\mathrm{N}$ - and $\mathrm{Q} / \mathrm{P}$-type voltage-dependent calcium $\left(\mathrm{Ca}^{2+}\right)$ channels and positively to A-type and inwardly rectifying potassium channels $\left(\mathrm{K}^{+}{ }_{\mathrm{A}}\right.$ and $\mathrm{K}^{+}{ }_{i r}$, respectively). Thus, there is enhanced outward $\mathrm{K}^{+}$current resulting in decreased cell firing, and closing of $\mathrm{Ca}^{2+}$ channels resulting in decreased release of neurotransmitters, resulting in an overall effect of cellular inhibition. PKA Protein kinase A. Adapted from reference 80

\section{Supraspinal sites of action}

It has been demonstrated that cannabinoids act at multiple levels in the modulation of nociceptive or pain-related transmission $(2,4,5)$. Intracerebroventricular administration of cannabinoids (37) suppresses tail-flick responses and spinal nociceptive responses (17). Direct brain injections into areas involved in descending inhibition of spinal nociceptive neurons elicits antinociceptive effects; these areas include the PAG in the midbrain, the RVM and the noradrenergic nucleus A5 in the medulla (38-40). Furthermore, microinfusion with the cannabinoid agonist WIN55,212-2 directly into the RVM in rats leads to increased 'off-cell' activity with increased tail-flick latencies, indicating that cannabinoids act directly within the RVM to affect off-cell activity (41). Additionally, cannabinoids have been shown to decrease noxious stimulus-evoked firing of nociceptive neurons in the ventral posterolateral nucleus of the thalamus as well as the RVM, with the latter being a demonstrated $\mathrm{CB}_{1}$ effect (4).

Through a series of experiments involving animal behaviour (tail flick) and extracellular single unit recordings from RVM neurons, along with administration of specific cannabinoid and opioid agonists and antagonists, it has been demonstrated that cannabinoids produce analgesia through the same brainstem circuit used for opioid analgesia. The use of an opioid is not required for the cannabinoid to produce this effect (42). In addition, both systemic and intracerebroventricular administration of cannabinoids have been shown to decrease noxious heat-evoked activity of wide dynamic range (WDR) neurons in a manner sensitive to spinalization, indicating a supraspinal site of action and descending modulation of WDR neurons (17).

\section{STM}

Spinal sites of action

Several investigators have demonstrated that cannabinoids also inhibit pain by a direct spinal action (16,43-49). These observations are consistent with labelling studies exhibiting the presence of cannabinoid receptors in the dorsal horn of the spinal cord. For example, cannabinoids can act at spinal $\mathrm{CB}_{1}$ receptors to inhibit capsaicin-sensitive fibres in lumbar dorsal horn slices and to decrease noxious stimulus-evoked firing of WDR neurons $(16,48)$. Additional evidence supports that activation of the spinal $\mathrm{CB}_{1}$ receptor can decrease $\mathrm{N}$-methylD-aspartate receptor activation, potentially by inhibiting glutamate release into the spinal cord (49).

Intrathecal injection of (methyl-6-phenylethynyl) pyridine, a selective metabotropic glutamate-5 receptor antagonist, reversed the antihyperalgesic effect of intrathecal WIN55,212-2 in a rat loose ligation sciatic nerve model (50).

These data suggest that the antihyperalgesic effect of cannabinoid agonist WIN55,212-2 is mediated through an interaction with spinal metabotropic glutamate-5 receptors (50). In addition, there is growing support that cannabinoids modulate spinal noradrenergic and opioid systems (see 'Opioid system' section) (4).

\section{Peripheral cannabinoid action}

Cannabinoids also act in the periphery. The endocannabinoids AEA and PEA have been found in the skin in concentrations five- to 10-fold higher than in brain or plasma in the rat (50). Evidence supports the presence of $\mathrm{CB}_{1}$ receptors on central and peripheral terminals of primary afferent neurons (2).

A number of studies have demonstrated a peripheral antinociceptive action for cannabinoid agonists in preclinical models (50-53); both $\mathrm{CB}_{1}(51,53)$ and $\mathrm{CB}_{2}$ receptor agonists (52) exhibit peripheral antinociceptive action.

Peripheral application of cannabinoids has also been demonstrated to reduce hyperalgesia and inflammation in preclinical models of neuropathic and inflammatory pain (51). Furthermore, it has been demonstrated that topical application of cannabinoid agonist (WIN55,212-2) enhances the antinociceptive effect of topical morphine via a $\mathrm{CB}_{1}$-mediated effect; in addition, spinally ineffective doses of WIN55,212-2 potentiate the antinociceptive effects of topical morphine (54).

\section{ENDOGENOUS PAIN MODULATION}

There is growing support that endocannabinoids participate in endogenous pain modulation. Supraspinally, in the PAG, it has been demonstrated that administration of cannabinoid antagonists produces hyperalgesia and blocks the analgesia produced by electrical stimulation of the dorsal PAG $(47,55)$. Furthermore, using microdialysis in the PAG along with liquid chromatography/mass spectrometry, it was established that the analgesia produced by electrical stimulation or by injection of the chemical irritant formalin into the hind paws of anesthetized rats was associated with the release of AEA in the PAG (56), supporting that either pain itself or electrical stimulation leads to the release of AEA, which then acts on cannabinoid receptors in the PAG to inhibit nociception. Spinally, it has been demonstrated that hypoactivity of the spinal cannabinoid system has been associated with N-methylD-aspartate-dependent hyperalgesia (49).

There is also support for peripheral control of pain initiation by endocannabinoids. Gas chromatography/mass spectrometry measurements indicate that the levels of AEA and 
PEA in the skin are enough to cause tonic activation of local
cannabinoid receptors. Furthermore, the $\mathrm{CB}_{1}$ antagonist SR141716A and the $\mathrm{CB}_{2}$ antagonist SR144528 prolong and enhance pain behaviour produced following formalin injection. This work supports participation of endocannabinoids in the intrinsic control of pain initiation at peripheral sites (50).

\section{CANNABINOIDS AND INTERACTIONS WITH OTHER SYSTEMS}

\section{Monoaminergic/noradrenergic systems}

There is evidence suggesting the involvement of monoaminergic systems in cannabinoid-induced antinociception. The serotoninergic neurotoxin 5,7-dihydroxytryptamine and the dopaminergic neurotoxin 6-hydroxydopamine both reduce the antinociceptive effect of cannabinoids in animal models. In these studies, noradrenergic involvement could not be ruled out due to the lack of pretreatment with a noradrenergic uptake inhibitor.

Intrathecal administration of yohimbine (an alpha-2adrenergic antagonist) blocked antinociceptive effects of $\Delta-9$ THC. In contrast, intrathecal injection of the nonspecific serotonin antagonist, methysergide, did not reduce $\Delta-9$ THC-induced antinociception, nor did serotonin depletion by $p$-chlorophenlyalanine, suggesting a lack of serotonin involvement in cannabinoid antinociception. Similarly, the alpha1-antagonist phenoxybenzamine failed to block cannabinoid antinociception. Taken together, these data support a role for the spinal noradrenergic system in cannabinoid-induced antinociception (3).

\section{Opioid system}

Studies have determined that the analgesic effect of THC is, at least in part, mediated through delta and kappa opioid receptors. THC administered intrathecally has been shown to release endogenous opioids that stimulate delta and kappa receptors (57). Delta antagonists do not interfere with cannabinoid antinociception. Dynorphin antisera and the selective kappa antagonist nor-binaltorphimine block THC-induced antinociception; this antagonism is specific to antinociception and occurs at the spinal level. Furthermore, dynorphin A (1-8) antiserum and antisense to the kappa-1 receptor antagonized the effect (2,3). In addition, a bidirectional cross tolerance of $\Delta-9$ THC and CP55,940 to kappa agonists has been demonstrated in the tail-flick test (58). Thus, the preponderance of data supports a role for kappa and delta opioid receptors in the mediation of a component of cannabinoid antinociception (57).

There is also some evidence supporting a possible role for mu opioid receptors in the enhancement of morphine antinociception by THC. Both naloxone and SR141716A ( $\mathrm{CB}_{1}$-specific antagonist) block the enhanced antinociception due to the combination of low-dose THC and morphine, supporting both $\mathrm{CB}_{1}$ and mu opioid roles in the synergy (57). Thus, the current literature supports the possible involvement of all three major opioid receptor subtypes involved in some part in the enhancement of opioids by THC (57).

It has been demonstrated that cannabinoids can act synergistically with the opioid receptor agonists in the production of antinociception in animal models of acute pain $(2,4)$. This synergy has been demonstrated in numerous studies, using several routes of administration (4), and the synergy works both ways, with cannabinoids enhancing opioid antinociception and morphine enhancing cannabinoid antinociception. Full isobolographic analysis has substantiated the greater than additive effect necessary to identify synergy (57).

Following chronic dosing, upregulation of opioid receptor protein in the spinal cord has been observed in combinationtreated animals and may play a role in retention of efficacy of the drug combination. Short-term administration of low-dose THC with morphine in mice attenuated opioid tolerance without the loss of the antinociceptive effect. Further prolonged exposure to a cannabinoid agonist failed to result in downregulation of delta opioid receptors in vitro. Taken together, these results support that cannabinoids can alter opioid tolerance (57). Thus, data support a synergistic effect of cannabinoids and opioids and a possible role for cannabinoids in situations of opioid tolerance.

\section{CANNABINOIDS AND PAIN}

Cannabinoids exhibit antinociceptive and antihyperalgesic effects in models of acute and chronic pain

Preclinical work reveals that cannabinoids block pain responses in virtually every pain model tested. One of the earliest studies was performed by Dixon (59), who demonstrated that cannabis was able to suppress canine reactions to pinpricks. In models of acute or physiological pain, cannabinoids are effective against thermal, mechanical and chemical pain and are comparable with opioids in potency and efficacy (5).

In models of chronic pain, cannabinoids exhibit greater potency and efficacy in both inflammatory (60) and neuropathic pain (61). Because cannabinoids are also able to affect motor systems, it is important to establish that the slowed reactions of animals in pain tests are not because of slowed motor activity rather than pain inhibition. In electrophysiological studies, it has been concluded that cannabinoids produce profound suppression of cellular nociceptive responses with no suppression of the low threshold mechanoreceptive neurons (5). These experiments include suppression of neurophysiological responses to all types of nociceptive stimuli tested, suppression of windup (a model of central sensitization observed in chronic pain) and suppression of increased spontaneous firing following injection of the inflammatory agent complete Freund's adjuvant $(2,5,17,18,62-65)$. Thus, there is significant evidence that cannabinoids exhibit antinociceptive and antihyperalgesic effects in models of acute and chronic pain.

Of further importance to chronic pain is the fact that upregulation of $\mathrm{CB}_{1}$ receptors (within the ipsilateral superficial dorsal horn of the spinal cord in rats following chronic constriction injury of the sciatic nerve) has been demonstrated. This enhanced the effects of a cannabinoid agonist (WIN55,212-2) on both thermal hyperalgesia and mechanical allodynia, supporting that upregulation of spinal cannabinoid receptors following peripheral nerve injury may contribute to the effects of exogenous cannabinoids in neuropathic pain (66). Furthermore, repeated administration of WIN55,212-2 given subcutaneously reversed the development of hyperalgesia that normally develops in chronic constriction of the sciatic nerve in rats (67), supporting that cannabinoids may play a role in prevention of neuropathic pain if given early after nerve injury.

\section{Nonpsychoactive cannabinoids targeting pain}

There is significant interest in the development of synthetic cannabinoids without psychotropic activity (68-70). Ajulemic acid (also called CT-3) is a synthetic analogue of $\Delta^{8}$-THC-11-oicacid, one of the endogenous transformation products of THC. 


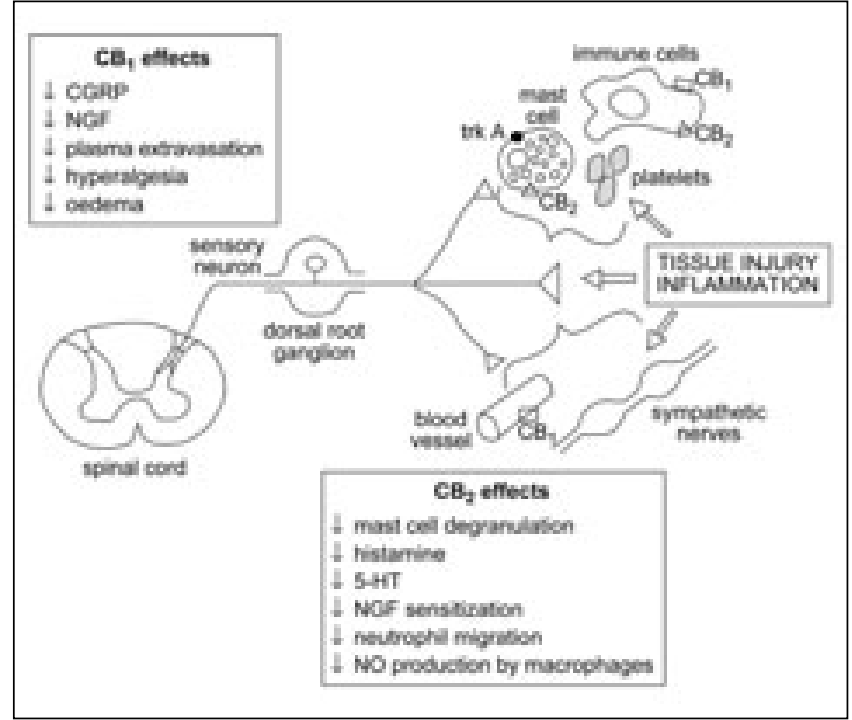

Figure 5) Cannabinoid influences on peripheral nerve activity with tissue injury and inflammation. 5-HT 5-hydroxytryptamine; $\mathrm{CB}_{1}$ Cannabinoid receptors found primarily in nervous system; $\mathrm{CB}_{2}$ Cannabinoid receptors found primarily in peripheral tissues/immune system; CGRP Calcitonin gene-related peptide; NGF Nerve growth factor; NO Nitric oxide; trk A High affinity NGF receptor. Figure adapted from reference 71

In preclinical studies, ajulemic acid has been found to exhibit potent analgesic, antiallodynic and anti-inflammatory activity; however, it binds to $\mathrm{CB}_{1}$ receptors and has been found to cause sedation in mice (70). Cannabidiol (CBD) is a nonpsychoactive cannabinoid present in cannabis that does not bind to cannabinoid receptors; it has also been demonstrated that CBD inhibits FAAH and blocks the reuptake of AEA, thus enhancing extracellular levels of AEA (71). Investigators have developed synthetic analogues to CBD in a search for a nonpsychoactive, nonsedating agent. HU-320 (CBD-dimethyl-heptyl-7oic acid) is a novel synthetic cannabinoid acid that has been demonstrated to exhibit strong anti-inflammatory and immunosuppressive properties while demonstrating no psychoactive effects (70).

\section{Anti-inflammatory and peripheral antihyperalgesic effects of cannabinoids}

Following tissue injury or inflammation with disruption in normal tissue integrity and migration of various cells (eg, immune and mast cells, platelets), a diversity of chemical mediators are produced or released locally. These mediators then activate peripheral sensory nerve endings. Some will activate the sensory nerve directly; others will sensitize the nerve to other stimuli or exert regulatory effects on the sensory neuron, inflammatory cells and adjacent sympathetic nerves (Figure 5) (72).

There is evidence that $\mathrm{CB}_{1}$ and $\mathrm{CB}_{2}$ receptors are present peripherally, and the mechanisms for synthesizing, releasing and inactivating endocannabinoids are present during inflammation (7).

$\mathrm{CB}_{1}$ agonists exhibit a direct effect on the sensory nerve terminal itself to inhibit release of calcitonin gene-related peptide (51) and inhibit sensitizing effects of nerve growth factor
(NGF) (7). Peripheral administration of AEA attenuates hyperalgesia and edema via a $C_{1}$ receptor mechanism and inhibits capsaicin-evoked plasma extravasation into the hindpaw (51).

Local analgesic actions of directly and indirectly acting agonists for $\mathrm{CB}_{2}$ receptors, expressed on mast cells and inhibiting mast cell function, have also been demonstrated $(50,52) . \mathrm{CB}_{2}$ receptor mechanisms may play a particularly prominent role in inflammatory pain (7). Both $\mathrm{CB}_{2}$ and high-affinity NGF receptors (trkA) have been identified on mast cells, and mast cells amplify the NGF signal during inflammation (7). There is increasing evidence that PEA (a $\mathrm{CB}_{2}$ agonist) attenuates this amplification. PEA accumulates in inflamed tissue, is synthesized by leukocytes, prevents mast cell degranulation and suppresses inflammatory hyperalgesia and edema (7). Furthermore, it has been demonstrated that neutrophil migration is diminished by endocannabinoids in models of inflammatory pain. In addition, cannabinoids attenuate nitric oxide production from stimulated macrophages via a $\mathrm{CB}_{2}$ receptor-mediated action (7), and have also been demonstrated to have profound and complex effects on cytokine production (73).

$\mathrm{A} \mathrm{CB}_{2}$ selective agonist (AM1241, administered intraperitoneally) suppressed development of intradermal capsaicininduced thermal and mechanical hyperalgesia and allodynia; this was reversed by a $\mathrm{CB}_{2}$ antagonist (SR144528) but not by a $\mathrm{CB}_{1}$ antagonist (SR141716A). Also, AM1241 suppressed thermally and mechanically evoked hyperalgesia and allodynia following local administration to the capsaicin ipsilateral paw but had no effect on the contralateral (untreated) paw. These data provide evidence that actions at $\mathrm{CB}_{2}$ receptors are sufficient to normalize nociceptive thresholds and produce antinociception in persistent pain states (74).

In animal models of inflammmatory pain, local administration of AEA, PEA and synthetic cannabinoids have been repeatedly demonstrated to attenuate behavioural responses to proinflammatory substances including subcutaneous formalin, capsaicin and complete Freund's adjuvant (7). A recent study (75) found that nabilone, a cannabinoid agonist available by prescription in Canada, reduced edema and associated hyperalgesia following carrageenan injection into the paw. It has also been demonstrated that AEA causes inhibition of interleukin-2 secretion in activated splenocytes via a mechanism involving both cyclooxygenase-1 and cyclooxygenase-2 (76). Old antiinflammatory analgesic drugs such as indomethacin and flurbiprofen activate $C_{1}$ receptors via a decrease in FAAH degradation and, therefore, an increase in AEA concentration, suggesting the potential for a cannabinoid mechanism of action contributing to their effects (77).

\section{Visceral pain conditions}

Manipulation of $\mathrm{CB}_{1}$ receptors can alter sensory processing from the gut; brain integration of the brain-gut axis; extrinsic control of the gut; and intrinsic control by the enteric nervous system (78).

The upper gastrointestinal tract is strongly influenced by $\mathrm{CB}_{1}$ receptor activation on central vagal pathways, whereas intestinal peristalsis can be modified by $\mathrm{CB}_{1}$ receptor activation in the absence of extrinsic input (78). Endocannabinoids (AEA and PEA) attenuate viscera-visceral hyperreflexia, spinal Fos expression and the referred hyperalgesia in a model of cystitis that shares features of interstitial cystitis; the effects 
COPYRIGHT PULSUS GROPP

of AEA are predominantly $\mathrm{CB}_{1}$ receptor-mediated and the
effects of PEA are predominantly $\mathrm{CB}_{2}$ receptor-mediated $(7)$.

$\mathrm{CB}_{1}$-deficient mice or wild-type mice administered $\mathrm{CB}_{1}$ antagonists exhibit increased inflammation following intrarectal administration of proinflammatory substances (eg, 2,4-dinitrobenzene sulphonic acid [DNBS]). Treatment with a cannabinoid agonist or genetic ablation of FAAH protected against the development of DNBS-induced colitis. Electrophysiological recordings from circular smooth muscle cells $8 \mathrm{~h}$ after the administration of DNBS revealed spontaneous action potentials in $\mathrm{CB}_{1}$-deficient mice but not in wildtype littermate colons, indicating early $\mathrm{CB}_{1}$-mediated control of inflammation-induced irritation of smooth muscle cells. DNBS treatment increased the percentage of myenteric neurons expressing $\mathrm{CB}_{1}$ receptors, suggesting enhanced cannabinoid signalling during colitis. This work supports evidence that $\mathrm{CB}_{1}$ receptors mediate intrinsic protective signals that counteract proinflammatory responses and indicates the endocannabinoid system is a promising target for the treatment of gastrointestinal disorders with excessive inflammatory responses (79).

\section{The future of cannabinoid research}

The present review has focused on cannabinoid research relating to pain applications. As presented in the introduction, there are many other potential applications for cannabinoid agonist and antagonist molecules under development. Perhaps the most exciting area of research regarding cannabinoids is the identification of ways to manipulate the endocannabinoid system. Unlike endogenous opioids, endocannabinoids are synthesized by what appear to be relatively selective enzymes. Furthermore, there is also intense focus on the mechanism of reuptake and inactivation of the endocannabinoids. In the future, it may be possible to manipulate the endocannabinoid system for the treatment of pain in much the same way as the monoaminergic system is targeted for the treatment of depression.

\section{CONCLUSION}

The potent antinociceptive and antihyperalgesic effects of cannabinoid agonists, the presence of cannabinoid receptors in pain-processing areas of the brain, spinal cord and periphery, and the endogenous modulation of pain systems by cannabinoids support that cannabinoids exhibit significant potential as analgesics.

\section{REFERENCES}

1. Gaoni Y, Mechoulam R. Isolation, structure and partial synthesis of an active constituent of hashish. J Am Chem Soc 1964;86:1646-7.

2. Pertwee RG. Cannabinoid receptors and pain. Prog Neurobiol 2001;63:569-611

3. Martin BR, Lichtman AH. Cannabinoid transmission and pain perception. Neurobiol Dis 1998;5:447-61.

4. Richardson JD. Cannabinoids modulate pain by multiple mechanisms of action. J Pain 2000;1:2-14.

5. Walker JM, Strangman NM, Huang SM. Cannabinoids and pain. Pain Res Manag 2001;6:74-9.

6. Rice AS. Cannabinoids and pain. Curr Opin Investig Drugs 2001;2:399-414.

7. Rice AS, Farquhar-Smith WP, Nagy I. Endocannabinoids and pain: Spinal and peripheral analgesia in inflammation and neuropathy. Prostaglandins Leukot Essent Fatty Acids 2002;66:243-56

8. Devane WA, Dysarz FA 3rd, Johnson MR, Melvin LS, Howlett AC. Determination and characterization of a cannabinoid receptor in rat brain. Mol Pharmacol 1988;34:605-13.
9. Matsuda LA, Lolait SJ, Brownstein MJ, Young AC, Bonner TI. Structure of a cannabinoid receptor and functional expression of the cloned cDNA. Nature 1990;346:561-4.

10. Munro S, Thomas KL, Abu-Shaar M. Molecular characterization of a peripheral receptor for cannabinoids. Nature 1993;365:61-5.

11. Sim LJ, Selley DE, Xiau R, Childers SR. Differences in G-protein activation by mu- and delta-opioid, and cannabinoid, receptors in rat striatum. Eur J Pharmacol 1996;307:97-105.

12. Herkenham M, Lynn AB, Johnson MR, Melvin LS, De Costa BR, Rice KC. Characterization and localization of cannabinoid receptors in rat brain: A quantitative in vitro autoradiographic study. J Neurosci 1991;11:563-83.

13. Mailleux P, Vanderhaeghen JJ. Distribution of neuronal cannabinoid receptor in the adult rat brain: A comparative receptor binding radioautography and in situ hybridization histochemistry. Neuroscience 1992;48:655-68.

14. Tsou K, Brown S, Sanudo-Pena MC, Mackie K, Walker JM. Immunohistochemical localization of cannabinoid CB1 receptors in rat central nervous system. Neuroscience 1998;83:393-411.

15. Herkenham M. Localization of cannabinoid receptors in brain and periphery. In: Pertwee RG, ed. Cannabinoid Receptors. New York: Academic Press 1995:145-66.

16. Hohmann AG, Tsou K, Walker JM. Cannabinoid modulation of wide dynamic range neurons in the lumbar dorsal horn of the rat by spinally administered WIN 55,212-2. Neurosci Lett 1998;257:119-22

17. Hohmann AG, Briley EM, Herkenham M. Pre- and postsynaptic distribution of cannabinoid and mu opioid receptors in rat spinal cord. Brain Res 1999;822:17-25..

18. Hohmann AG, Herkenham M. Cannabinoid receptors undergo axonal flow in sensory nerves. Neuroscience 1999;92:1171-5.

19. Pertwee RG. Pharmacology of cannabinoid CB1 and CB2 receptors. Pharmacol Ther 1997;74:129-80.

20. Sanudo-Pena MC, Tsou K, Delay ER, Hohmann AG, Force M, Walker JM. Endogenous cannabinoids as an aversive or counterrewarding system in the rat. Neurosci Lett 1997;223:125-8.

21. Wenger T, Fernandez-Ruis JJ, Ramos JA. Immunohistochemical demonstration of CB1 cannabinoid receptors in the anterior lobe of the pituitary gland. J Neuroendocrinol 1999;11:873-8.

22. Klein TW. Cannabis and immunity. In: The Health Effects of Cannabis. Kalant H, Corregal W, eds. Toronto: Centre for Addiction and Mental Health, 1999:349-73.

23. Klein TW. Cannabinoids and the immune system. Pain Res Manage 2001;6:95-101.

24. Gong JP, Onaivi E, Uhl G. Cannabinoid CB2 receptors: Immunhistochemical localization in rat brain. ICRS abstracts. 15th Annual Symposium on the Cannabinoids, Clearwater, Florida, June 24-27, 2005.

25. Devane WA, Hanus L, Breuer A, et al. Isolation and structure of a brain constituent that binds to the cannabinoid receptor. Science 1992;258:1946-9.

26. Mechoulam R, Ben-Shabat S, Hanus L, et al. Identification of an endogenous 2-monoglyceride, present in canine gut, that binds to cannabinoid receptors. Biochem Pharmacol 1995;50:83-90.

27. Sugiura T, Kondo S, Sukagawa A, et al. 2-Arachidonoylglycerol: A possible endogenous cannabinoid receptor ligand in brain. Biochem Biophys Res Commun 1995;215:89-97.

28. DePetrocellis L, Cascio MG, DiMarzo V. The endocannabinoid system: A general view and latest additions. Br J Pharmacol 2004;141:765-74.

29. Bisogno T, Melck D, Bobrov MY, et al. N-acyl-dopamines: Novel synthetic $\mathrm{CB}(1)$ cannabinoid-receptor ligands and inhibitors of anandamide inactivation with cannabimimetic activity in vitro and in vivo. Biochem J 2000;351:817-24.

30. Huang SM, Bisogno T, Trevisani M, et al. An endogenous capsaicin-like substance with high potency at recombinant and native vanilloid receptors. Proc Natl Acad Sci 2002;99:8400-5.

31. Porter AC, Sauer JM, Knierman MD, et al. Characterization of a novel endocannabinoid, virodhamine, with antagonist activity at the CB1 receptor. J Pharmacol Exp Ther 2002;301:1020-4.

32. Mukhopadhyay S, Shim JY, Assi AA, Norford D, Howlett AC. CB(1) cannabinoid receptor-G-protein association: A possible mechanism for differential signaling. Chem Phys Lipids 2002;121:91-109.

33. DiMarzo V, Bifulco M, DePetrocellis L. The endocannabinoid system and its therapeutic exploitation. Nat Rev Drug Discov 2004;3:771-84 
34. Lichtman AH, Martin BR. The selective cannabinoid antagonist SR 141716A blocks cannabinoid-induced nociception in rats. Pharmacol Biochem Behav 1997;57:7-12.

35. Howlett AC. Pharmacology of cannabinoid receptors. Ann Rev Pharmacol Toxicol 1995;35:607-34.

36. Wilson RI, Nicoll RA. Endocannabinoid signaling in the brain. Science 2002;296:678-82.

37. Martin WJ, Lai NK, Patrick SL, Tsou K, Walker JM. Antinociceptive actions of WIN 55,212-2 following intraventricular administration in rats. Brain Res 1993;629:300-4.

38. Martin WJ, Patrick SL, Coffin PO, Tsou K, Walker JM. An examination of the central sites of action of cannabinoidinduced antinociception in the rat. Life Sci 1995;56:2103-10.

39. Martin WJ, Tsou K, Walker JM. Cannabinoid receptor-mediated inhibition of the rat tail-flick reflex after microinjection into the rostral ventromedial medulla. Neurosci Lett 1998;232:33-6.

40. Martin WJ, Coffin PO, Attias E, Balinsky M, Tsou K, Walker JM. Anatomical basis for cannabinoid-induced antinociception as revealed by intracerebral microinjections. Brain Res 1999;822:237-42.

41. Meng ID, Manning BH, Martin WJ, Fields HL. An analgesia circuit activated by cannabinoids. Nature 1998;395:381-3.

42. Meng ID, Johansen JP. Antinociception and modulation of rostral ventromedial medulla neuronal activity by local microinfusion of a cannabinoid receptor agonist. Neuroscience 2004;124:685-93.

43. Yaksh TL. The antinociceptive effects of intrathecally administered levonantradol and desacetyllevonantradol in the rat. J Clin Pharmacol 1981;21:334S-40S.

44. Welch SP, Stevens DL. Antinociceptive activity of intrathecally administered cannabinoids alone and in combination with morphine in mice. J Pharmacol Exp Ther 1992;262:10-8.

45. Lichtman AH, Martin BR. Spinal and supraspinal components of cannabinoid-induced antinociception. J Pharmacol Exp Ther 1991;258:517-23.

46. Lichtman AH, Martin BR. Cannabinoid-induced antinociception is mediated by a spinal alpha 2-noradrenergic mechanism. Brain Res 1991;559:309-14

47. Richardson JD, Aanonsen L, Hargreaves KM. SR141716A, a cannabinoid receptor antagonist, produces hyperalgesia in untreated mice. Eur J Pharmacol 1997;319:R3-4.

48. Richardson JD, Aanonsen L, Hargreaves KM. Antihyperalgesic effects of spinal cannabinoids. Eur J Pharmacol 1998;345:145-53.

49. Richardson JD, Aanonsen L, Hargreaves KM. Hypoactivity of the spinal cannabinoid system results in NMDA-dependent hyperalgesia. J Neurosci 1998;18:451-7.

50. Calignano A, la Rana G, Giuffrida A, Piomelli D. Control of pain initiation by endogenous cannabinoids. Nature 1998;394:277-81.

51. Richardson JD, Kilo S, Hargreaves KM. Cannabinoids reduce hyperalgesia and inflammation via interaction with peripheral CB1 receptors. Pain 1998;75:111-9.

52. Malan TP, Ibrahim MM, Deng H, et al. CB2 cannabinoid receptormediated peripheral antinociception. Pain 2001;93:239-45.

53. Dogrul A, Husamettin G, Akar A, Yildiz O, Bilgin F, Guzeldemir E. Topical cannabinoid antinociception: Synergy with spinal sites. Pain 2003;105:11-6.

54. Yesilyurt O, Dogrul A, Gul H, et al. Topical cannabinoid enhances topical morphine antinociception. Pain 2003;105:303-8.

55. Strangman NM, Patrick SL, Hohmann AG, Tsou K, Walker JM. Evidence for a role of endogenous cannabinoids in the modulation of acute and tonic pain sensitivity. Brain Res 1998;813:323-8.

56. Walker JM, Huang SM, Strangman NM, Tsou K, Sanudo-Pena MC. Pain modulation by release of the endogenous cannabinoid anandamide. Proc Nat Acad Sci (USA) 1999;96:198-203.

57. Cichewicz DL. Synergistic interactions between cannabinoid and opioid analgesics. Life Sci 2004;74:1317-24.

58. Smith PB, Welch SP, Martin BR. Interactions between delta-9. tetrahydrocannabinol and kappa opioids in mice. J Pharmacol Exp Ther 1994;268:1381-7.

59. Dixon WE. The pharmacology of cannabis. Indica Br Med J 1899;2:1354-7.

60. Tsou K, Lowitz KA, Hohmann AG, et al. Suppression of noxious stimulus-evoked expression of fos-like immunoreactivity in rat spinal cord by a selective cannabinoid agonist. Neuroscience 1995;70:791-8

61. Herzberg U, Eliav E, Bennett GJ, Kopin IJ. The analgesic effects of $\mathrm{R}(+)$-WIN 55,212-2 mesylate, a high affinity cannabinoid agonist, in a rat model of neuropathic pain. Neurosci Lett 1997;221:157-60.

62. Hohmann AG, Martin WJ, Tsou K, Walker JM. Inhibition of noxious stimulus evoked activity of the spinal cord dorsal horn neurons by the cannabinoid WIN 55,212-2. Life Sci 1995;56:2111-9.

63. Hohmann AG, Herkenham M. Regulation of cannabinoid and mu opioid receptors in rat lumbar spinal cord following neonatal capsaicin treatment. Neurosci Lett 1998;252:13-6.

64. Martin WJ, Hohman AG, Walker JM. Suppression of noxious stimulus-evoked activity in the ventral posterolateral nucleus of the thalamus by the cannabinoid WIN 55,212-2: Correlation between electrophysiological and antinociceptive effects. J Neurosci 1996;16:6601-11.

65. Strangman NM, Walker JM. The cannabinoid WIN 55,212-2 inhibits the activity-dependent facilitation of spinal nociceptive responses. J Neurophysiol 1999;82:472-7.

66. Lim G, Sung B, Ji RR, Mao J. Upregulation of spinal cannabinoid1-receptors following nerve injury enhances the effects of Win $55,212-2$ on neuropathic pain behaviors in rats. Pain 2003;105:275-83

67. Costa B, Colleoni M, Conti S, et al. Repeated treatment with the synthetic cannabinoid WIN 55,212-2 reduces both hyperalgesia and production of pronociceptive mediators in a rat model of neuropathic pain. Br J Pharmacol 2004;141:4-8.

68. Burstein SH, Audettte CA, Breuer A, et al. Synthetic nonpsychotropic cannabinoids with potent anti-inflammatory, analgesic, and leukocyte antiadhesion activities. J Med Chem 1992:35:3135-41.

69. Burstein SH, Stebulis JA, Torres R, et al. Ajulemic acid, a nonpsychoactive cannabinoid acid, downregulates activation of human synovial cells. ICRS 2004, abstract 209.

70. Sumariwalla PF, Gallily R, Tchilibon S, Fride E, Mechoulam R, Fledmann M. A novel synthetic, nonpsychoactive cannabinoid acid (HU-320) with antiinflammatory properties in murine collagen-induced arthritis. Arthritis Rheum 2004;50:985-98.

71. Bisogno T, Hanus L, De Petrocellis L, et al. Molecular targets for cannnabidiol and its synthetic analogues: Effect on vanilloid VR1 receptors and on the cellular uptake and enzymatic hydrolysis of anandamide. Br J Pharmacol 2001;134:845-52.

72. Sawynok J. Topical and peripherally acting analgesics. Pharm Rev 2003;55:1-20.

73. Klein TW, Lane B, Newton CA, Friedman H. The cannabinoid system and cytokine network. Proc Soc Exp Biol Med 2000;225:1-8.

74. Hohmann AG, Farthing JN, Zvonok AM, Makriyannis A Selective activation of cannabinoid CB2 receptors suppresses hyperalgesia evoked by intradermal capsaicin. J Pharmacol Exp Ther 2004;308:446-53.

75. Conti S, Costa B, Colleoni M, Parolaro D, Giagnoni G. Antiinflammatory action of endocannabinoid palmitoylethanolamide and synthetic cannabinoid nabilone in a model of acute inflammation in the rat. Br J Pharmacol 2002;135:181-7.

76. Rockwell C, Kaminski N. Anandamide metabolites from both cyclooxygenase enzymes cause inhibition of Il-2 secretion in murine splenocytes. ICRS 2004 Abstract 210.

77. Fowler CJ. Possible involvement of the endocannabinoid system in the actions of three clinically used drugs. Trends Pharmacol Sci 2004;25:59-61.

78. Hornby PJ, Prouty SM. Involvement of cannabinoid receptors in gut motility and visceral perception. Br J Pharmacol 2004;141:1335-45.

79. Massa F, Marsicano G, Hermann H, et al. The endogenous cannabinoid system protects against colonic inflammation. J Clin Invest 2004;113:1202-9.

80. Ameri A. The effects of cannabinoids on the brain. Prog Neurobiol 1999;58:315-48 


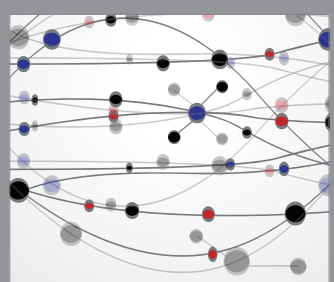

The Scientific World Journal
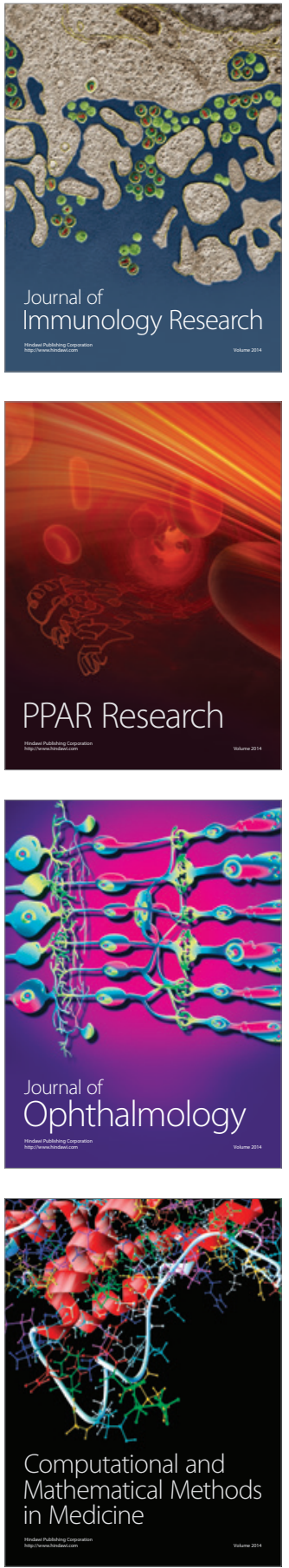

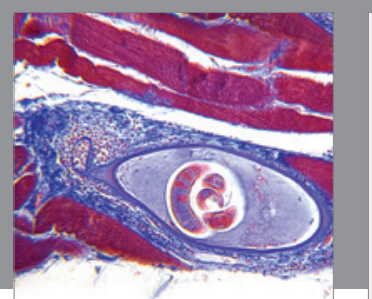

Gastroenterology Research and Practice

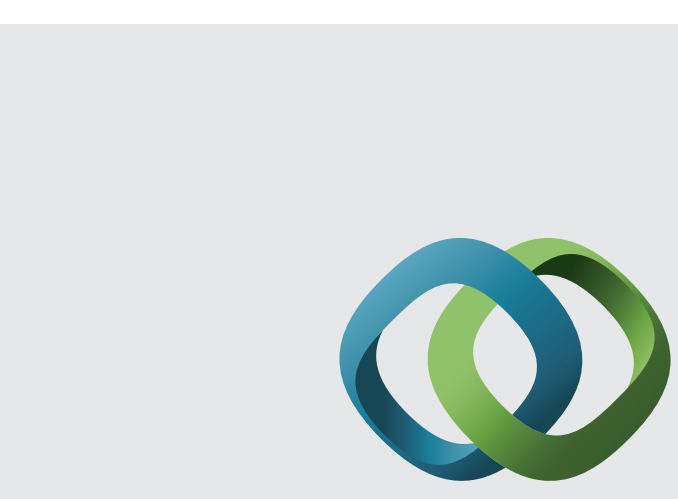

\section{Hindawi}

Submit your manuscripts at

http://www.hindawi.com
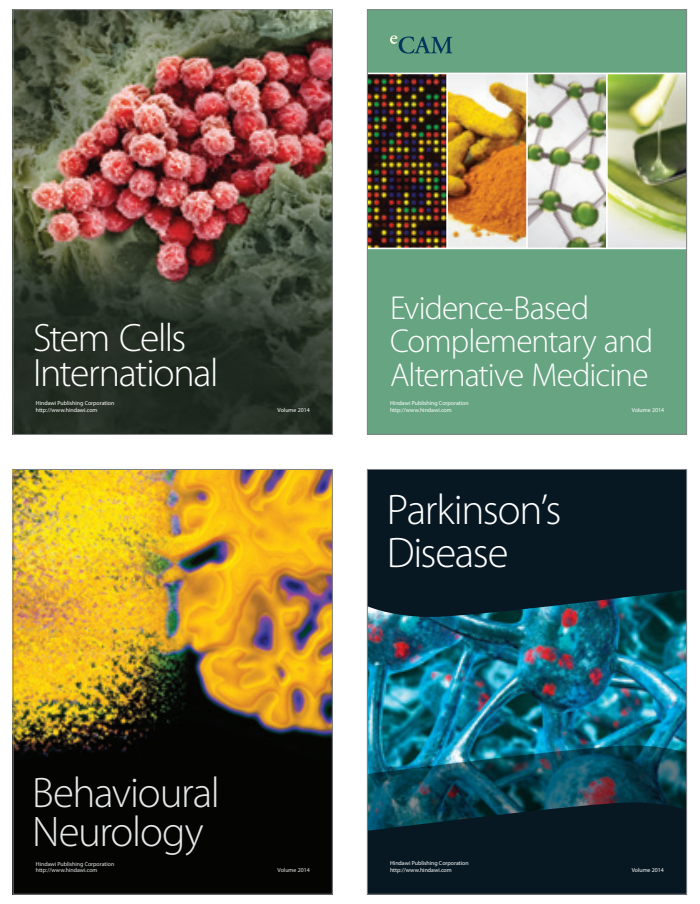
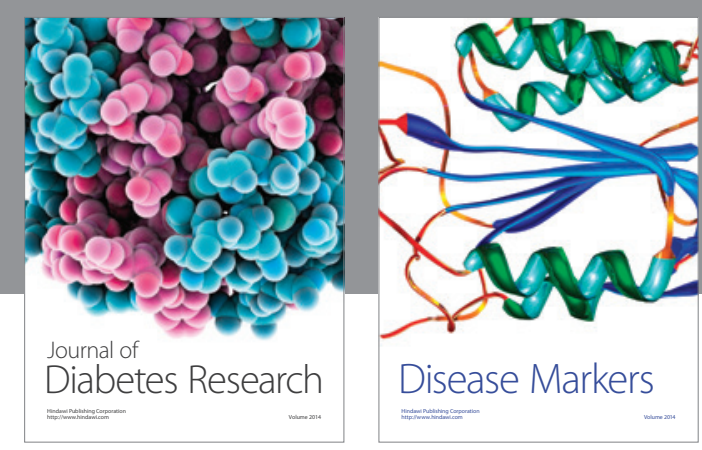

Disease Markers
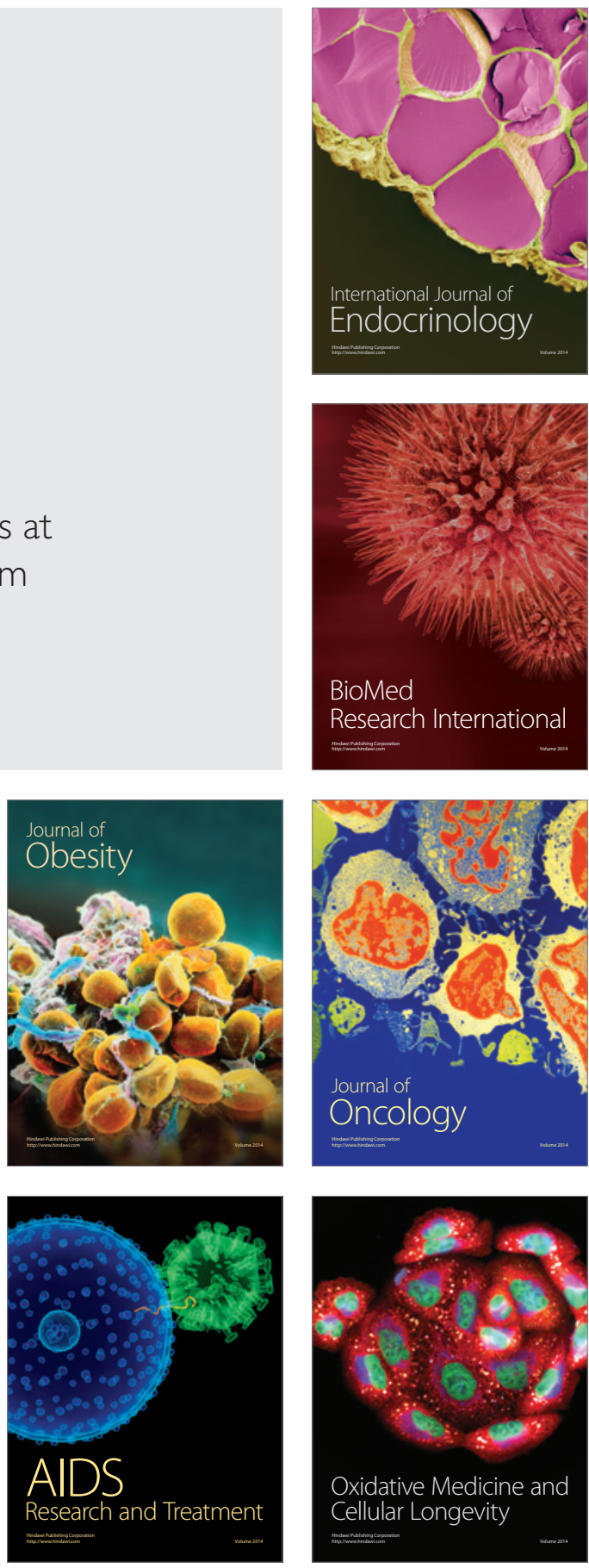